\title{
RENEWABLE ENERGY FOR THE RURAL AREAS: SELF-SUFFICIENCY OR A NEW ECONOMIC BRANCH?
}

\author{
Antonín VAISHAR • Milada ŠŤASTNÁ • Kateřina STONAWSKÁ • Jana ŽITŇÁKOVÁ \\ Mendel University in Brno \\ Zemědělská 1, 61300 Brno, Czechia \\ antonin.vaishar@mendelu.cz•stastna@mendelu.cz•katerina.stonawska@mendelu.cz•jana.zitnakova@mendelu.cz
}

\begin{abstract}
The paper is discussing the role of energy production from renewable sources in the rural areas of Central Europe, the South-Moravian Region (Czechia) being the case study area. Based on this example the problems with the use of water, wind, sun, geothermal and biological sources for the energy production are illustrated. The environmental, technological, economic and social aspects of the matter are discussed. It was concluded that the use of renewable sources for decentralised energy production and consumption is strongly recommended for the rural areas. Concerning the mass production, the use of the biological sources seems to be meaningful. In the case of other sources, rural communes should be careful taking into account an environmental and economic impact and also the acceptance of local inhabitants.
\end{abstract}

Key-words: renewable energy sources, rural areas, mass production, decentralisation, South-Moravian Region.

\section{Introduction}

Energy production from the renewable sources belongs to topical economic trends. Recoverability and, thus, sustainability is the main argument. The necessity to reduce pollution from fossil fuels and fear of nuclear power plants is usually the second one. In the reality, this method of the energy production began in 1970s as a response to the oil Crisis. The production of energy from renewable sources is space-inefficient. It requires a relative large space which is available usually in the rural areas. On the other hand, renewable sources could be an optimum solution in spacious rural areas in the developing countries which are not yet connected to the medium voltage networks. Decrease of energy dependency on central distribution could be also an argument - especially in the future. Our society is highly dependent on electric power. It could collapse in a few hours after the power supply interruption. All these arguments support the idea of the energy production from renewable sources in terms of a prospective rural economic branch (Št'astná et al. 2012).

However, the production of the electric power from renewable sources is controversial for several reasons. First of all, there is a basic contradiction between short-time economic interests of producers, distributors and consumers of energy (which are in con- 
cordance with the neo-liberal ideology) and long-term public interests (as sustainability of the production, landscape aesthetic, nature protection, keeping the employment in the rural areas etc.). Also public interests are often inconsistent: is landscape protection more important than the employment, is sustainability of the energetic policy more important than protection of animals? The approach "not in my backyard" (van der Horst 2007; Frantál 2008) welcoming the production of energy from renewable sources provided that it is produced in another location is also frequent.

Dispersion and difficult prediction of such a production belong to its main complications. Diametrical structural differences among individual types of renewable energy sources add to it. That is why it is almost impossible to apply unified solutions for large territories but it is necessary to look for trajectories how to evaluate specific potential of each region and how to use it for streamlined implementation. The South-Moravian Region is our case study area in this regard.

\section{Theory, methodology, data}

According to the Czech definition, "Renewable sources consist of non-fossil natural energetic sources, namely energy of the wind, energy of solar radiation, geothermal energy, energy of water, soil, air, biomass, landfill gas, sewer gas and bio-gas" (Law No. 180/2005 Coll.). In general, biomass, solar, water, wind and geothermal energy are among those which may currently be used.

The rural area is a place where a large part of the renewable energy sources (RESs) can originate. First of all, this concerns bio-energetic resources. Their production is a part of the agriculture and forestry. Some authors even see the future or the revival of the rural areas in such a production (see e.g. Knappe 2009). But also big solar or wind parks which require a lot of space are situated in the rural landscape as a rule. Rapid development of RESs changes rural landscape to a wide extent (Vaishar et al. 2011). Yellow fields of the rape cultivated for the energetic use remain to be typical for the Moravian agricultural land. Wind turbines are landscape marks in some territories. Large solar fields situated often on the agricultural soil of the highest quality are integral part of the South-Moravian rural areas. The latter type of RESs evokes the question of the food security (e.g. Nonhebel 2005).

However, the rural areas are also an important consumer of electric power. RESs (especially solar, wind or geothermal sources) are suitable also for covering the energy demand of individual buildings or grounds. Rural residences, production grounds or service equipment fit it. In this way, distribution network losses and dependency on them could be eliminated. Hain et al. (2005) shows that production of energy from RESs at the local level could at least significantly improve the energetic balance of the country.

Energy production from RESs has also its externalities. Bergmann et al. (2006) specify impacts on the landscape, nature and air quality. They also take the employment and energy prices into account. Elliott (2000) shows how problematic it is to use the RESs as a part of the sustainable development in the conditions of obsolete institutional, market and industrial relations. Neo-liberal economy with its only criterion of short-term individual profit is in direct contradiction with the principles of sustainability which are based on three pillars - economic, social and environmental. 
The problematic nature of RESs consists in their recoverability. Conventional fossil resources were formed for millions of years and they are fully available now. It depends on mankind only how much and when humans draw them. On the other hand, RESs are available at any time according to the specific situation and people depend on their instantaneous quantity. This represents a basic problem, since no efficient method of energy storage exists so far.

The development of the energy production from RESs meets a number of barriers which have been described, e.g. by Painuly (2001). He divided these barriers into economic, technological, market, institutional, social and environmental ones, and defined the criteria for the selection of an appropriate source as follows: (1) availability of the relevant sources (natural condition), (2) availability of appropriate technologies, (3) commercial and financial sustainability, (4) environmental damage and benefits, (5) socio-economic effects, including job creation.

Social acceptance is one of the crucial questions connected with the development of the energy production from RESs (Wüstenhagen et al. 2007). Lack of wide acceptance of this method of energy production among the population affected may become a major barrier. The acceptance of RESs is naturally connected with its perception which has environmental, economic and psychological aspects. It is known that disproportion between a general agreement for RES and resistance to specific projects exists. However, as shown by Rogers et al. (2008), the local projects are accepted substantially more favourably than big ones aimed at delivery of the energy into the network against financial profit. On the other hand, a support for local projects from central sources is expected.

It is also necessary to take into the account that the public does not represent any homogeneous group in relation to the RESs but it consists of different interest and world view groups. Their attitude toward the problem can be quite different (West et al. 2010). Serdianou and Genoudi (2013) show that this type of energy is preferred by educated medium aged people with higher incomes. Actually, it is necessary to identify such groups in the affected area and to choose streamlined information tactics. Zoellner et al. (2008) show that two aspects are important to increase the public awareness: economic advantage and public involvement in the decision-making process.

The access to innovations in the rural areas could be one of the positive impacts of RESs utilization. Carpenter et al. (2013) stated that (often criticized) support to the wind energy in Germany became the impetus for an inclusion of marginal niches to the mainstream.

The study is aimed at the evidence of the RESs utilization in the case study area (the South-Moravian Region). Problems of the power production from renewable sources are discussed in terms of self-sufficiency of the rural areas on the one hand and in terms of an economic branch bringing new jobs and economic benefit to the rural areas on the other.

The empirical part of the study is based on an analysis of energy production from renewable sources in the South-Moravian Region in general and according to individual types. Official data were provided mainly by Energostat, Energy Regulatory Authority (ERÚ), Czech Energy Company (ČEZ) and Czech Statistical Office (ČSú). Individual RESs are evaluated and discussed from the viewpoint of their availability, efficiency and externalities related to the rural development.

There were also other methods used: field research analysing individual types of RESs in detail, SWOT analysis (using a brainstorm of experts of five institutions dealing with rural problems) and also a questionnaire aimed at the perception of RESs. The investigations mentioned are not a direct subject of this paper. 


\section{Energy production from renewable sources}

About $20 \%$ of energy (mostly obtained from biomass and water) is produced from RESs worldwide. Figure 1 shows the development of energy production from RESs in the EU countries. Because the hydropower belongs to the most traditional RESs, countries with the best conditions to produce this type of energy are in the lead. It also shows that the present level of the energy production from RESs is relatively modest in Czechia.

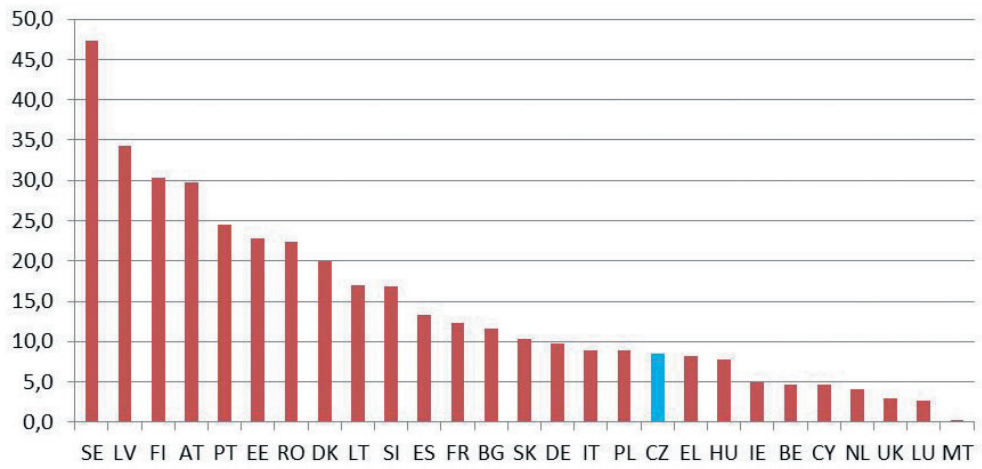

Fig. 1. Share of RESs in the energy production in the EU countries 2009 [\%] Source: EU (2013).

Table 1 shows the share of RESs in the total energy balance of Czechia. The national energy sources are based on coal and nuclear fuels in more than $90 \%$, whereas oil and natural gas are mostly imported. This energetic base is not very favourable. Except for the nuclear energy, it represents a combination of environmentally unfriendly and imported sources and, therefore, energetic dependency. The problem is also aggravated by the fact that the installed capacity of the nuclear power plants is used in $75 \%$ during the year, coal power plants in 55\% whereas power plants using RESs in 10-20\% only. Thus, their efficiency is extremely low.

Table 1. Energy resources in Czechia in 2009

\begin{tabular}{|l|c|c|}
\hline \multicolumn{1}{|c|}{ Source } & Own sources [\%] & $\begin{array}{c}\text { Including export and import } \\
\text { [\%] }\end{array}$ \\
\hline Coal and coal-gas & 66,9 & 41,8 \\
Nuclear & 22,7 & 16,9 \\
Combustible bio-sources and wastes & 8,1 & 5,6 \\
Oil and oil-products & 0,9 & 21,7 \\
Water sources & 0,7 & 0,5 \\
Natural gas & 0,5 & 16,0 \\
Solar, wind, geothermal & 0,1 & 0,1 \\
\hline
\end{tabular}

Source: Aggregated Energetic Balance, Czech Statistical Office, Praha. 
Figure 2 shows the recent development. The year 2010 recorded a peak in the area of construction of the solar power plants. This was caused by a massive non-system support of the solar energy production. The cause spoiled the perception of RESs among people due to substantial damage to the landscape, occupation of agricultural soils, and especially due to an increase in energy prices. Nevertheless, the energy production from RESs slowly increases. The most recent data show that 8,055 GWh of energy from RESs (2012) have been produced, which corresponds to $11.43 \%$.

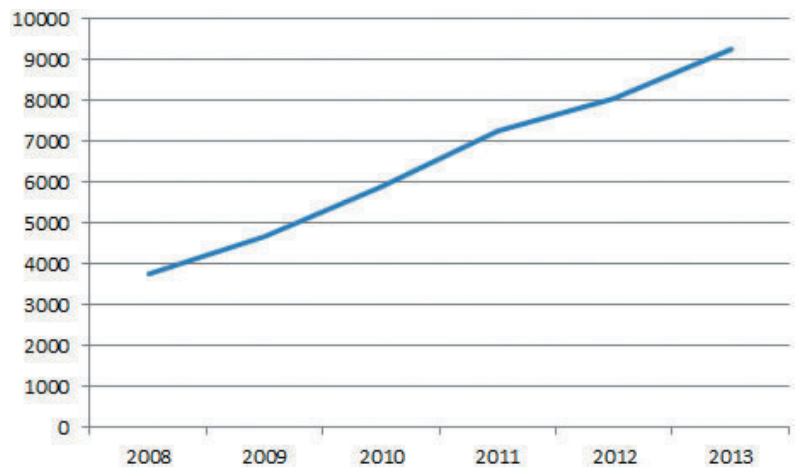

Fig. 2. Development of the energy production from RESs in 2008-2013 Source: ERÚ (2014).

The Figure 3 shows shares of individual sources. Water was the main source of energy production among RESs recently. It is a traditional source used since medieval ages, but its capacities are almost exhausted. The biomass is more promising, especially in terms of substitution of traditional crops with energetic plants. As it was said, the solar energy has recorded important increase in 2010. These three sources are currently balanced. The other three sources play a complementary role, although there are prospects for the energy obtained from wastes.

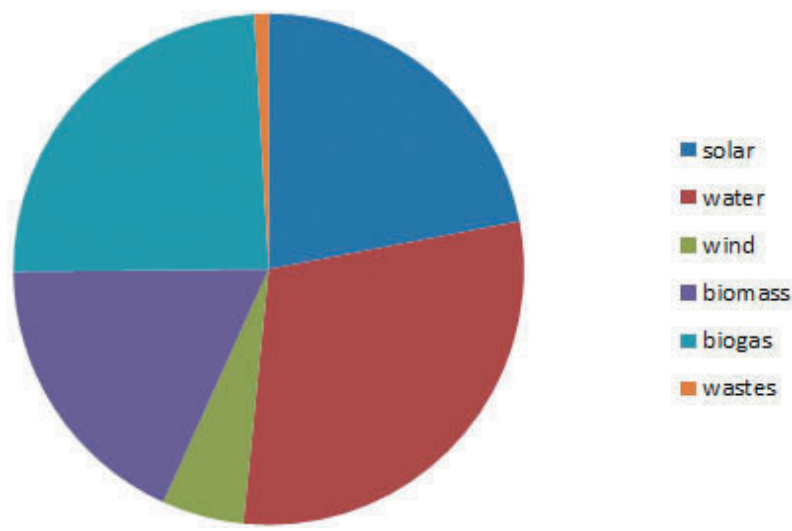

Fig. 3. Shares of individual sources on the total energy production from RESs. Source: ERÚ (2014). 
Czech Energetic Policy presupposes a decrease of fossil fuel use which should be realized by transition to nuclear energy and RESs. The share of RESs should reach $13 \%$ in 2020 which is fully realistic. Biomass should play the main role among RESs (the production should be limited to assure the food security of the country). This policy is challenged by many: neo-liberals (who prefer leaving all economic policies to the market powers), opponents of the nuclear energy (but Czech population has provisionally a positive attitude towards the nuclear energy), various groups interested in specific types of energy etc.

The use of coal for the energy and heat production in the South-Moravian Region is minimal. There are no current environmental problems connected with the energy production (except for vehicle fuel). On the other hand, the heat economy depends to a large extent on the mostly imported natural gas, which makes region dependent on foreign energy sources. This is why the search for better utilization of RESs has its sense also in this respect.

Natural conditions of the region play an important role. The water reservoirs of Vranov, Nové Mlýny and Brno-Kníničky constitute relatively large sources of water energy. They have affected the original landscape a lot - including the destruction of some rural settlements. Today, all three reservoirs are the main tourist and leisure destinations in the region. These power plants are supplemented by about sixty small water power plants. Actually, the accessible water sources have been used almost completely.

On the other hand, among all Czech regions this one has the best conditions for the use of solar energy. Situated in the south-east of the country, the South-Moravian Region records the most intensive insolation (Fig. 4). Therefore, the amount of solar energy produced is the largest among the Czech regions. According to Aquatest Co., there are 2.2 million of solar panels in the region with the total installed capacity of $447 \mathrm{MW}$. But as it was mentioned above, the big solar power plants were booming on the agricultural land in 2010. In the future construction of solar panel on the buildings or degraded land (brownfields) mainly comes into consideration.

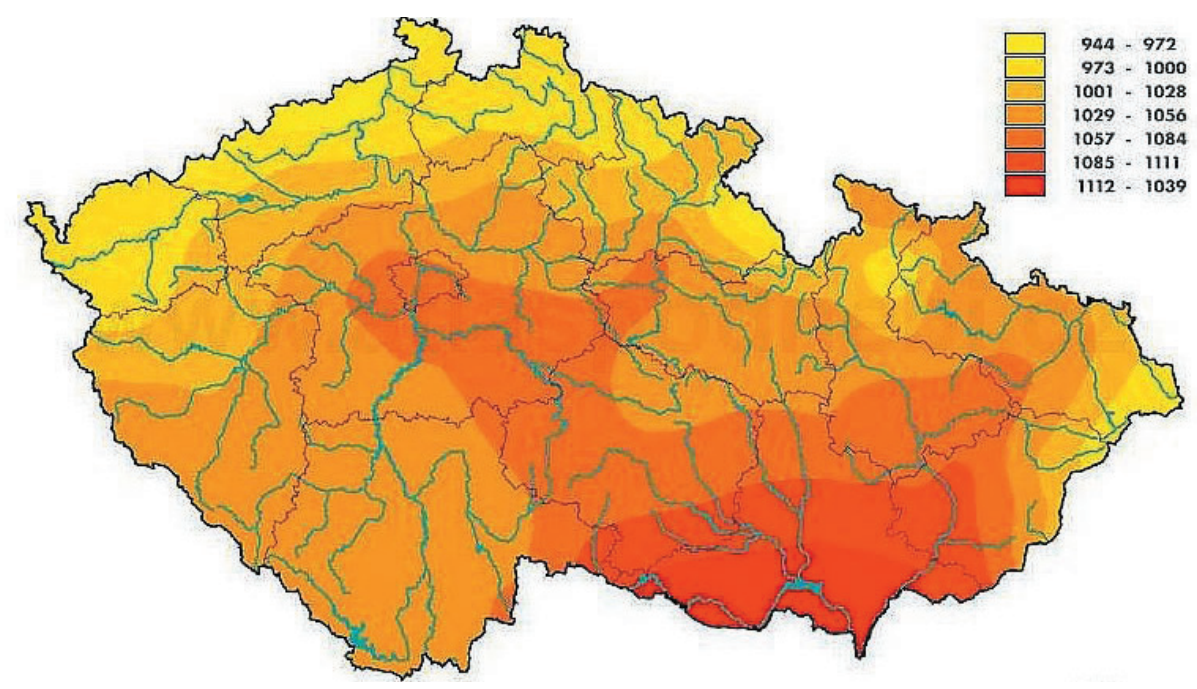

Fig. 4. Annual balance of sunshine $[\mathrm{kWh} / \mathrm{m} 2]$ 1961-2000 Source: Tolasz et al. (2007). 
In contrast to the solar energy there are very poor conditions for the use of wind energy in the region (Cetkovský et al. 2010). The wind speed is insufficient across the majority of the territory (Fig. 5). The tops of mountain ranges where the speed of the wind is higher are included into the protected landscape. Only three wind parks are installed in the region. All other plans were rejected due to conflicts with landscape and/or birds protection (NATURA 2000). Similarly, the use of the geothermal energy has hardly any prospects in southern Moravia. According to the Ministry of Environment of the Czech Republic, there are only low-potential sources of the geothermal energy in the region, which are suitable for local heating and/or balneology purposes. There are two balneotherapy projects under implementation (Pasohlávky, Lednice) and one (Klobouky) is being designed.

Biomass for production of energy is the most prospective source among RESs in the South-Moravian Region which is known as a rural and agricultural territory. Moreover, the production of energy in agriculture has additional (sometimes the most attractive) impact: ensuring agricultural production and jobs after the download of food production (Järvelä et al. 2009) and a solution of the problem of waste elimination. Figure 6 illustrates an increasing use of bio-sources in the Czech Republic. The increasing production from bio-sources is evident. The minimum production from biologically degraded communal waste is the only puzzling aspect.

Both the purpose-grown plants (Fig. 7) and the post-harvest reminders of the conventional crops are used for the energy production. The bio-sources are used for heating, for combined heat and electricity production, for gas production and for vehicle biofuel production. The latter is not carried out in the region because the biofuel plants are situated in distant regions. The production of wood mass for heating is popular but this source is almost exhausted due to the landscape and biodiversity protection.

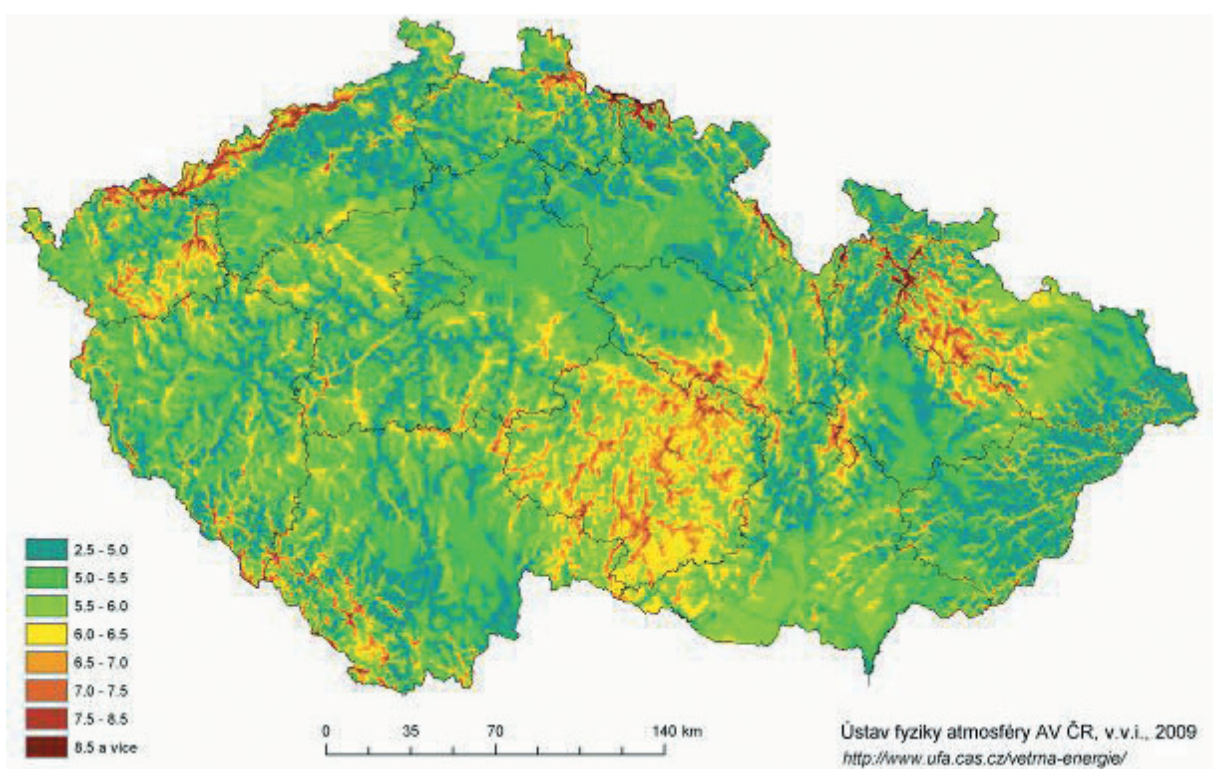

Fig. 5. Average wind speed at the height of $100 \mathrm{~m}$ above the ground surface Source: Praha, Institute of Atmospheric Physics, Czech Academy of Sciences; http://www.ufa.cas.cz/struktura-ustavu/oddeleni-meteorologie/projekty-egp/vetrna-energie/vetrna-mapa.html 


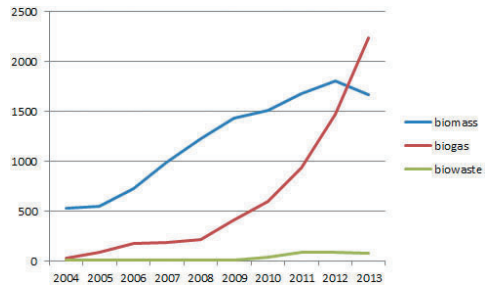

Fig. 6. Production of the energy from biological sources 2004-2013 in the Czech Republic [MWh]. Source: ERU (2014).

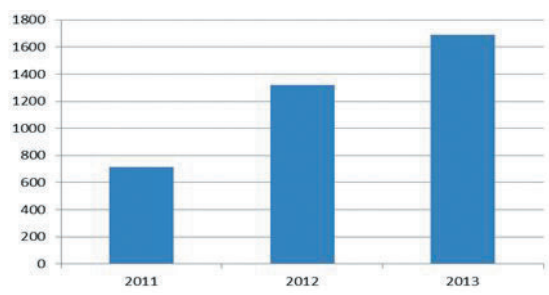

Fig. 7. Czechia: Sowing areas of energetic plants 2011-2013 [ha]. Source: Sowing areas 2007-2013, Czech Statistical Office, Praha.

\section{Discussion: Different externalities connected with the RESs use for energy production}

Usually, the environmental, technological, economic and social aspects of RESs are discussed. A decrease in greenhouse gas emissions is not only a clear positive aspect of the RESs use for the energy production but it is one of the main motivations for the whole activity. However, some adverse impacts have also been noted - not to mention environmental externalities of the production, transport and ecologically destructive impact of wind turbines, solar panels and other equipment used in this sector. The environmental problems are caused by the equipment construction, damage to the landscape type and also by some local problems of noise, smell and some other aspects of the individual plant operation. The intensity of the mentioned impact depends often on the size and localization of individual equipment.

The annual and daily fluctuations constitute the main technological disadvantage of RESs use for the energy production (except for the geothermal energy). In particular, the wind and solar plants are subject to the current meteorological situation. Water and bio-energy are also typically seasonal sources. Consumption also has its annual and daily fluctuations (Figs. 8 and 9). However both fluctuations can have different patterns - this is especially visible at the annual level. In the Central Europe conditions the peak demand for energy is recorded in winter when the offer of RESs is limited. Moreover, the specific amounts are only hardly predicable in the longer term - particularly in respect of wind, sunshine or floods. For such cases it is necessary to have some conventional backup sources.

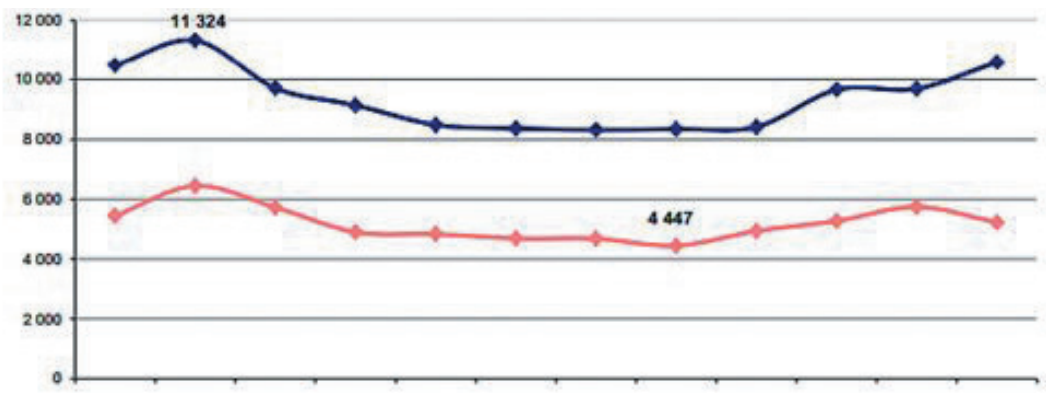

Fig. 8. Maximum and minimum energy consumption during a year Source: ERÚ (2014). 


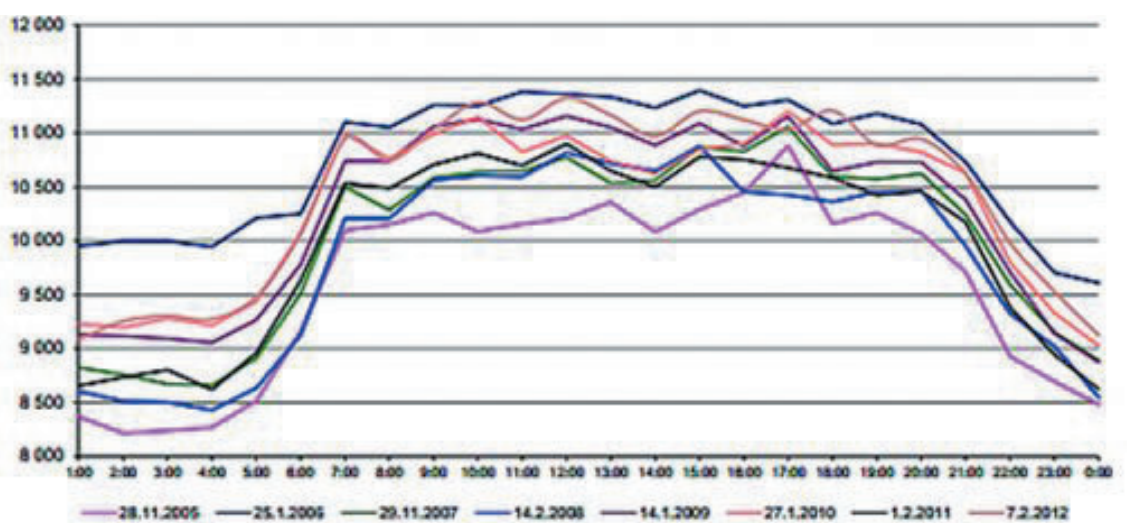

Fig. 9. Daily consumption with maximum energy consumption Source: ERÚ (2014).

The economic aspects are connected with the production costs and energy prices. It is usually assumed that RESs are more expensive compared to the conventional fuels. Actually, for the solar, wind, geothermal and water sources the fixed costs are very high whereas the operational costs are extremely low. This is an optimum situation for the support of the mentioned RESs. Firstly - the fixed costs are known at any time and do not depend on the later price developments. Secondly - this is consistent with the EU philosophy which provides for the support of investments rather than operation. The way taken by Czechia - guarantee of high purchase price of energy - was false and resulted in its quick collapse. The problem is that this "mistake" has badly affected the reputation of RESs and led to the total withdrawal of support for RESs.

Energy prices are a function of private individual short-term relation between costs and benefits. The question of price depends on what is included in the costs. In particular, the use is linked with the costs of externalities which are usually not included in the individual costs. Table 2 shows prices of individual energy sources with and without of environmental costs of coal externalities. When the externalities are not included in the price, the coal is unrivalled cheapest source (especially after the price fall in connection with the use of shale gas in the USA). However, if the cost of externalities is included into the prices, RESs start to be competitive. How to create the political will for inclusion of costs of externalities into the coal purchase prices is a problem beyond the scope of this article. Heal (2010) claims the total lack of a discussion of this topic. When the non-renewable resources draw near their exhaustion, an increase of their prices could be expected. Though this is a question of a distant future, it could be reasonable to take it into account.

If the producers of non-renewable sources do not pay for the externalities, do the consumers accept some extra-payments for using RESs? Based on the example of the English town Bath Longo et al. (2008) found that the citizens would accept such extra-payments in the amount of 16-98 USD annually. But it is unlikely that the situation in Czechia would be similar.

As far as social aspects are concerned, it is usually assumed that the energy production from RESs has a positive impact on the job market. Based on the example of the USA Kammen et al. (2004) shows, that RESs generate relatively large number of jobs whereas Lehr et al. (2008) believe (based on the example of Germany) that such an impact is rela- 
tively small and could be increased only with the export of such energy. Logically - if the use of water, wind, solar and geothermal energy sources implies low operational costs, these sources are most probably not able to generate jobs. The increase in job number comes into consideration only in the case of biological sources with higher operational costs.

Table 2. Prices of individual energy resources 2008

\begin{tabular}{|l|c|}
\hline \multicolumn{1}{|c|}{ Source } & Price [CZK/kWh $]$ \\
\hline Coal (without externalities) & 1.18 \\
Geothermal energy & 1.87 \\
Residual biomass & 2.50 \\
Wind energy & 2.60 \\
Water energy & 2.80 \\
Coal with externalities & 2.82 \\
Bio-gas & 3.20 \\
Biomass (energetic plants) & 3.60 \\
\hline
\end{tabular}

Source: European Commission (2008).

The greatest positive social impact of RESs use consists probably in the improvement of human health due to a decrease in the greenhouse emissions. But such an impact is hardly quantifiable and it is dispersed across the Earth whereas people are interested usually in their local conditions.

The social effects of the energy production from RESs, including obstacles and controversies of its development, were described by Mautz et al. (2008). The authors emphasize the conflict of two basic paradigms. On the one hand, there are the use of fossil and nuclear fuels, centralised production and distribution and oligopoly branch structure. On the other hand, we have decentralised production and consumption, plural structure of actors and ecology as a leading motive aim to promote.

The latter is important especially for the rural areas. Devine-Wright (2005) shows, that the use of RESs for energy production under a decentralized system could gain the support of the local inhabitants. This circumstance could be important in the process of community planning (Walker and Devine-Wright 2008). On the other hand, local people increasingly oppose to the mass production of energy from RESs - especially when the benefits are leaving the place of the production. Huttunen (2011) points out that the question is not easy. It is necessary to specify individual models of production to reach the true social sustainability.

\section{Conclusion: self-sufficiency or a new sector of economy?}

What type of the energy production from RESs is attractive and suitable for the rural development? Based on the aspects listed above it is clearly possible to recommend a development of decentralized systems of energy production and consumption in the rural areas. It provides a set of advantages: 
- Use of local sources for local production, including a reduction of the transport needs

- Reduced dependency on the centralized market and its prices

- Reduced dependency on the transmission networks and their problems (including black-outs)

- Enhanced responsibility of inhabitants in the area of energy management

- Friendly acceptance by local people.

As for the mass production, the use of biological sources is recommended for following reasons:

- Production of biological energy sources is inherent in agriculture and forestry. The rural populations are prepared and qualified for it

- Biological energy sources are the only ones to generate jobs which are extremely important in the peripheral rural areas in particular.

The European experts agree more or less that the future of the rural areas lies in the multifunctionality. This concerns both agriculture as a sector and development of other sectors. The multifunctionality of agriculture is reflected (besides of the conventional production) in the landscape maintenance, eco-agriculture, development of agritourism and in the production of energy plants. This is also true for forestry: not only the production of wood but also non-wood production, ecological, water management and recreational functions, as well as the production of wood biomass. In this sense, growing ecological plants extends the multifunctionality of primary economy sectors which are inseparably linked with the rural areas (agribusiness in the economic theory).

However, hydropower, wind and solar power plants are also concentrated in the rural space because of their extremely low territorial productivity. Is this production a sector of rural area or a sector which is only situated in the rural area? It would be suitable to ask a question what could bring this production to rural areas. The number of jobs for individual localities is very limited. The financial benefits depend on the investor and owner of the land where the equipment is installed. Usually, local populations have neither necessary financial resources nor necessary technological and organisational knowledge. It could mean that investors would often be not local.

That is why in the case of such RESs for mass energy production in the rural areas, it is recommended to be very careful. In principle, it is important to mediate optimum conditions for local settlements and their inhabitants. The experience collected from the case studies shows that small villages could cover a significant part of their budgets with the payments of the energy producers. But it has to be negotiated in advance. If not, the energy production from renewables is not a new sector for the rural areas, but a sector consuming the rural areas.

So, the question whether to open the rural areas to the mass energy production of energy from RESs has not been answered conclusively. The use of rural areas for the mass energy production depends in each individual case on the specific assessment both experts and local people. Anyway monitoring of the developments is a task for future research. 


\section{Acknowledgement}

The paper was elaborated within the grant project Nr. TP7/2013 of the Internal Grant Agency of the Faculty of Agronomy, Mendel University in Brno named "South-Moravian countryside as a space for the energy production from renewable sources".

\section{References}

Bergmann A., Hanley N., Wright R., 2006, Valuing the attributes of renewable energy investments, Energy Policy, 34, 9, pp. 1004-1014.

Carpenter J., Simmie J., Conti E., Povinelli F., Kipshagen J. M., 2013, Innovation and new path creation: the role of niche environments in the development, European Spatial Research and Policy, 19, 2, pp. 87-101.

Cetkovský S., Frantál B., Štekl J., 2010, Větrná energie v České republice: hodnocení prostorových vztahů, environmentálních aspektů a socioekonomických souvislosti, Ústav geoniky Akademie věd České republiky, Brno.

Devine-Wright P., 2005, Local aspects of UK renewable energy development: exploring public beliefs and policy implications, Local Environment: The International Journal of Justice and Sustainability, 10, 1, pp. 57-69.

Elliott D., 2000, Renewable energy and sustainable futures, Future, 32, 3-4, pp. 261-274.

ERÚ, 2014, Ročnízpráva o provozu eneregtické soustavy ČR zarok 2013, Energetic Regulatory Office, Praha.

EU, 2008. The support of electricity from renewable energy sources, Retrieved from http://ec.europa.eu/energy/climate_actions/do/2008_res_workingdocument_en.pdf Accessed September 30, 2013.

EU, 2013, Energy in Figures, Publications Office of the European Union, Luxembourg.

Frantál B., 2008, Větrné elektrárny a NIMBY syndrom: analýza faktorů ovlivňujicích vnímání a postoje obyvatel k rozvoji využiti větrné energie, [in:] Udržitelná energie a krajina 2008, Veronica, Brno, pp.21-25.

Hain J. J., Ault G. W., Galloway S. J., Cruden A., Mcdonald J. R., 2005, Additional renewable energy growth through small-scale community-orientated energy policies, Energy Policy, 33, 9, pp. 1199-1212.

Heal G., 2010, Reflections - The economics of renewable energy in the United States, Review of Environmental Economics and Policy, 4, 1, pp. 139-154.

Horst D. van der, 2007, NIMBY or not? Exploring the relevance of location and the politics of voiced opinions in renewable energy sitting controversies, Energy Policy, 35, 5, pp. 2705-2714.

Huttunen S., 2011, Bioenergy production and social sustainability on Finnish farms, [in:] Järvelä M., Juhola S. (eds.), Energy, Policy and the Environment, Springer, New York, pp. 173-192.

Järvelä M., Jokinen P., Huttunen S., Puupponen A., 2009, Local food and renewable energy as emerging new alternatives of rural sustainability in Finland, European Countryside, 1, 2, pp. 113-124.

Kammen D. M., Fripp M., Kapadia K., 2004, Putting renewables to work: how many jobs can the clean energy industry generate, Berkeley, University of California, RAEL report.

Knappe E. (ed.), 2009, Vom Landwirt zum Energiewirt - die Landwirtschaft Südosteuropas zwischen Euphorie und Skepsis, Leibnitz-Institut für Länderkunde, Leipzig. 
Lehr U., Nitsch J., Kratzat M., Lutz C., Adler D., 2008, Renewable energy and employment in Germany, Energy Policy, 36, 1, pp. 108-117.

Longo A., Markandya A., Petrucci M., 2008, The internalization of externalities in the production of electricity: willingness to pay for the attributes of a policy for renewable energy, Ecological Economics, 67, 1, pp. 140-152.

Mautz R., Byzio A., Rosenbaum W., 2008, Auf dem Weg zur Energiewende, Universitätsverlag, Göttingen.

Nonhebel S., 2005, Renewable energy and food supply: will there be enough land?, Renewable and Sustainable Energy Reviews, 9, 2, pp. 191-201.

Painuly J. P., 2001, Barriers to renewable energy penetration: a framework for analysis, Renewable Energy, 24, 1, pp. 73-89.

Rogers J. C., Simmons E. A., Converi I., Weatherall A., 2008, Public perception of opportunities for community-based renewable energy projects, Energy Policy, 36, 11, pp. 4217-4226.

Serianou E., Genoudi P., 2013, Which factors affect the willingness of consumers to adopt renewable energy?, Renewable Energy, 57, September 2013, pp. 1-4.

Štastná M., Kniezková T., Náplavová M., 2012, Embedding of rural businesses in the South Moravian region, European Countryside, 3, 3, pp. 198-207.

Tolasz R., Brázdil R., Buliirr O., Dobrovolný P., Dumbrovský M., Hájková L., Halásová O., Hostýnek J., Janouch M., Kohut M., Krška K., Křivancová S., Květoň V., Lepka Z., Lipina P., Macková J., Metelka L., Míková Z., Mrkvica Z., Možný M., Nekovář J., Němec L., Pokorný J., Reitschläger D., Richterová D., Rožnovský J., Řepka M., Semerádová D., Sosna V., Stř̌ž M., Šercl P., Škáchová H., Štěpánek P., Štěpánková P., Trnka M., Valeriánová A., Valter J., Vaníček K., Vavruška F., Voženílek V., Vráblík T., Vysoudil M., Zahradníček J., Zusková I., Žák M., Žalud Z., 2007, Atlas podnebí Česka, Český hydrometeorologický ústav, Universita Palackého, Praha, Olomouc.

Vaishar A., Jakešová L., Náplavová M., 2011, Current problems of South-Moravian landscape, European Countryside, 3, 4, pp. 265-281.

Walker G., Devine-Wright P., 2008, Community renewable energy: What should it mean?, Energy Policy, 36, 2, pp. 497-500.

West J., Bailey I., Winter M., 2010, Renewable energy policy and public perceptions a renewable energy: A cultural theory approach, Energy Policy, 38, 10, pp. 5739-5748.

Wüstenhagen R., Wolsink M., Bürer M. J., 2007, Social acceptance of renewable energy innovation: An introduction to the concept. Energy Policy, 35, 5, pp. 2683-2691.

Zoellner J., Schweizer-Ries P., Wemheuer C., 2008, Public acceptance of renewable energies: results from case studies in Germany, Energy Policy, 36, 11, pp. 4136-4141. 
http://rcin.org.pl 